\title{
The Spatial Ecology of the Timber Rattlesnake (Crotalus horridus) in southeastern Louisiana
}

\author{
Timothy Borgardt ${ }^{1}$, Brian Crother $^{1}$, and Kaleb Hill ${ }^{2}$ \\ ${ }^{1}$ Southeastern Louisiana University \\ ${ }^{2}$ University of Northern Colorado
}

December 8, 2021

\begin{abstract}
The Timber Rattlesnake (Crotalus horridus) has a large distribution spanning much of the eastern United States. Because temperature, habitat type, prey composition and abundance, and a variety of other factors may dictate reptile behavior, populations of conspecific species may exhibit behavioral differences across latitudinal and elevational gradients. Using radio telemetry, we tracked 10 adult Timber Rattlesnakes ( 7 males, 3 females) from May 2016 to June 2017 in southeastern Louisiana to examine the spatial ecology of male and non-gravid female snakes. Mean annual and seasonal home ranges of non-gravid female Timber Rattlesnakes were not statistically different from that of males. Mean seasonal home range sizes and average distances travelled of both sexes was smallest in winter, and had a general increasing trend beginning in spring with a peak in fall. These increases seemed to coincide with the breeding season, taking place from early July until the end of November. Comparison of this study with other studies throughout its distribution could have implications towards future management of conservation for other southern populations of Timber Rattlesnakes.
\end{abstract}

\section{Introduction}

The advancement of radio-telemetry for wildlife studies has allowed researchers to study the natural history of cryptic animals at a higher resolution than ever before (Ujvari and Korsos 2000). Understanding the spatial ecology of species and the temporal, biological, and ecological factors controlling it is vital for implementing conservation strategies for many species (Greene and Campbell 1992). This type of research is especially important for temperate pitviper species, such as the Timber Rattlesnake (Crotalus horridus ), especially those that migrate long distances annually, exhibit communal denning behaviors, and inhabit areas near human activity centers. Anthropogenic activities causing habitat fragmentation and structural changes that disrupt foraging and den sites, migration routes, prey densities, and many other aspects of species' life cycles and behaviors may be the greatest threat to pitviper populations (Andrews and Gibbons 2008, Green and Campbell 1992). The Timber Rattlesnake is especially vulnerable to these types of changes because of its long lifespan, low reproductive output, and habitat requirements (Beaupre and Douglas 2009).

The movement patterns and home range use of the Timber Rattlesnake have been extensively studied in central and northern portions of its range, mostly above the $35^{\circ} \mathrm{N}$ latitude (Brown 1982, Brown et al. 1982, Martin 1992, Reinert and Zappalorti 1988, Reinert and Rupert 1999, Sealy 2002, Waldron et al. 2006b). In northern latitudes, populations of snakes across multiple taxa migrate away from winter hibernacula during the active season and return before the onset of the dormant season (Bauder et al. 2016). This pattern is evident in populations of Timber Rattlesnake, with males and non-gravid females generally migrating from their hibernacula in spring and traveling in a looping pattern during the active season that returns them to the same hibernacula before temperatures drop below 15 in the fall or winter (Brown et al. 1982, Reinert and Rupert 1989, Reinert and Zappalorti 1988). 
Many snake species with large geographic ranges appear to exhibit more pronounced migratory behavior at higher latitudes than lower latitudes (Carfagno and Weatherhead 2008, Klug et al. 2011, Reed and Douglas 2002, Rodriguez-Robles 2003). For example, a study on home range sizes of the Grand Canyon Rattlesnake (Crotalus viridis abysus ) found that a population in Arizona had significantly smaller home range sizes than northern populations in Wyoming. The researchers attributed this difference to higher prey abundance and suitable microhabitat for hibernation and thermoregulation in the Arizona study area as compared to the patchy distribution of prey and suitable microhabitat in Wyoming (Reed and Douglas 2002). With a large distribution spanning much of the eastern, northeastern, southeastern, and central United States (Powell et al. 2016), it is possible that the Timber Rattlesnake exhibits divergent spatial ecology patterns depending on geographic location.

Determining the extent, scale, and conditions by which movement patterns and other aspects of a species' natural history differ among populations is important because data from localized studies are often extrapolated to represent other populations (Gomez and Gregor 2015). Using extrapolated data to guide conservation and management practices can create problems if such data do not represent the population being managed. Because there are no published studies describing the spatial ecology of the Timber Rattlesnake in Louisiana, any information regarding home ranges and movement patterns must be extrapolated from populations studied in other areas. Our study compares the annual and seasonal movement patterns and home range sizes of males and non-gravid females in a population of Timber Rattlesnakes in southeastern Louisiana. Results from our study will provide insight into differences or similarities that may exist in the spatial ecology of a population at the extreme southern extent of the species' range.

\section{Materials and Methods}

\section{Field site description}

We conducted our study on four tracts of land within a $16 \mathrm{~km}^{2}$ area of Orleans Parish, southeastern Louisiana, which we refer to as: "Site B", "Site H", "Site M," and "Site F" (Fig. 2).

Site B encompasses a 118 ha stretch of second-growth bottomland hardwood and degraded forest within the Bayou Sauvage National Wildlife Refuge. This narrow strip of hardwood forest is situated on a natural levee, causing an elevation gradient from $-52 \mathrm{~cm}$ to $111 \mathrm{~cm}$ as one moves from the marsh to the forest (Wall and Darwin 1999). It is bordered by a four-lane highway to the south, a two-lane highway to the east, marsh and open water to the north, and a gravel road paralleling a large bayou to the west. The central and northeastern portion of the site is populated by Chinese Tallow (Triadica sebifera), Live Oak (Quercus virginiana), Bald Cypress (Taxodium distichum), and a variety of other wetland tree species. Only a few areas in the central part of the study site have an abundance of coarse woody debris. Much of this debris consists of deadfall from Live Oak and Bald Cypress trees that died following Hurricane Katrina in 2005 (Howard 2012). The vegetation in the southwestern portion of Site B mostly consists of emergent vegetation, such as Chinese Tallow, Elderberry (Sambucus nigra), and Giant Reed (Arundo donax). Saw Palmetto (Serenoa ripens ), a few Live Oak, and Common Hackberry (Celtis occidentalis ) are also present. The central and northeastern portions are dominated by Possumhaw holly (Ilex decidua), especially at lower elevations, with patches of live oak at higher elevations.

Site $\mathrm{F}$ is located on the east side of the canal bordering Site B. It is privately-owned land dominated by weeds and vines, such as Blackberry (Rubus sp. ) and Common Cinquefoil (Potentilla simplex). The invasive Chinese Tallow is also present. There are a few scattered Live Oak, Bald Cypress, and Water Oak (Quercus nigra) present, but most of the habitat at this site would best be described as an open canopy, unmaintained field. At the time of our study, most of the land was not being maintained, allowing emergent vegetation to become the bulk of the plant biomass. This site is bordered by a four-lane highway to the south, a gravel road and a bayou to the east, a small canal to the west, and a major interstate to the north.

Site $\mathrm{H}$ is a privately-owned, 46 ha tract of land located approximately $2.5 \mathrm{~km}$ from Site B. Small transects of the property are managed for hunting activities and New Orleans electric power infrastructure, but most of the area is unmaintained forest. The forested area is dominated by Chinese Tallow and is mostly a closed 
canopy habitat with large amounts of deadfall. The site is bordered by a levee system to the south, urban development to the east, a canal and gravel road to the west, a larger canal to the northeast, and a gravel road and large body of shallow water to the northwest. Because it is located far from the natural levee built by the abandoned Mississippi River distributary, it is an area of low elevation that is sometimes inundated with water during times of high precipitation or when the water table is higher than normal.

Site $\mathrm{M}$ is an 82 ha tract of privately-owned land located approximately $3 \mathrm{~km}$ from Site B. Only a small portion of the northwestern area of this site is maintained. It has a few grass trails approximately $5 \mathrm{~m}$ in width that are cut with a bush hog pulled by a large tractor biweekly. The northern and northwestern boundaries are delineated by a canal approximately $50 \mathrm{~m}$ wide and a moderately-used four-lane road. The northeastern side of the property abruptly turns into a large, grass field used for cement and rock storage, and further northeast is a large canal and major interstate. The southern and southeastern areas are contiguously forested, with the dominant vegetation consisting of Chinese Tallow, Holly, and Carolina Ash (Fraxinus caroliniana). All the forested areas have an abundance of coarse woody debris, consisting of fallen trees and branches. This site has the highest elevation and best-drained soils.

\section{Snake capture and transmitter implantation}

We found snakes for this study by scouting the study area in the winter for possible hibernacula and suitable habitat. In March of 2016, eight snakes (five males and three non-gravid females) were captured on top of or near three separate hibernacula. These individuals were transported to Southeastern Louisiana University where Wildlife Materials International temperature-sensitive transmitters were implanted using published methods approved by the Southeastern University IACUC (Reinert and Cundall, 1982, IACUC Protocol \#0035). The first three anterior rattles were painted a unique color of finger nail polish to facilitate visual identification. After surgery, each snake was given approximately one week to recover in a secure enclosure with a hide box and water bowl. Upon recovery, individuals were released at their original capture sites. While tracking already implanted snakes, we captured an additional male snake and a non-gravid female snake in May of 2016. These snakes were collected, implanted with transmitters, and released using the methods described above. On June 7, 2016, one of the female snakes died for unknown reasons. The transmitter from this female was implanted into a male found within the study area and subsequently released. Observations of this individual began on June 15, 2016, and ended on June 4, 2017. In addition, the transmitter signal of one of the male snakes in the study was lost on December 8, 2016. This individual was not recovered.

Data collected from the deceased female were not used in any statistical analyses. Data collected from the lost male were not used for the statistical analyses of annual movements, but data collected during monthly intervals with full data sets were used in the statistical analyses of seasonal behavior. At the end of the study, all snakes with working transmitters were recaptured, brought back to Southeastern Louisiana University for transmitter removal and released at capture sites.

\section{Telemetry and data collected}

We tracked snakes using a Wildlife Materials International, Inc., receiver with a three element Yagi antenna approximately once per week for one year, April 2016-May 2017. After locating a snake, we recorded date, time, and latitude/longitude using a Garmin Oregon 600 GPS unit. For each observation, we recorded the behavior of the snake as foraging, resting, moving, hidden, or breeding (if copulation was observed). We also recorded a basic description of the location (vegetation type, canopy closure, soil type, habitat type, etc.), weather conditions, and any relevant behavioral observations.

\section{Movement and home range analyses}

We utilized ArcMap 10.2 (ESRI, 2011) to create maps of the study sites with aerial photography images (1 meter resolution). We imported GPS data from each snake as separate map layers, and generated home ranges for each snake using the Home Range Tools (HRT) for ArcGIS 2.0.20 extension (Rodgers et al. 2015). We calculated home ranges using the kernel density estimate application in HRT. The kernel method is a non-parametric approach to estimating a Utilization Distribution (UD), a probability distribution of areas 
utilized by an animal using the locations it has previously used. It frees the UD from any parametric assumptions, making better use of locational data (Worton 1989).

We calculated annual home range estimates for each snake that had nine months or more data. Prior to analyses, we deleted duplicate GPS points (if an individual was found at the same location at consecutive recordings) to avoid skewing results. We generated a polygon representing the $90 \%$ isopleth and $50 \%$ isopleth for each snake (Fig. 3). For this study, we defined the total home range of an individual by the area encompassed within the $90 \%$ isopleth, and defined the activity core, or area most utilized by the individual, as the area encompassed within the $50 \%$ isopleth. We chose these values because most other studies use these criteria, allowing for easy comparisons among studies. We also generated seasonal home ranges for each snake using three-month intervals representing seasons (December-February, winter; March-May, spring; June-August, summer; September-November, fall). We only used data from individuals that were tracked throughout each three-month interval to calculate mean seasonal home range and activity core sizes.

We also used the HRT extension to generate the distance between successive relocations for each snake. We used these results and equation 1 to calculate the average distance moved between successive relocations in each month. We then calculated the average for each three month season.

$$
D=\frac{\sum_{i=x_{1}}^{x_{n}} d_{i}}{\mathrm{n}}
$$

Equation 1: Average distance moved between successive relocations.

${ }^{1} D$ is the average distance moved between successive relocations in a month

${ }^{2} d$ is the distance moved between each successive relocation

${ }^{3} n$ is the total number of movements

\section{Statistical analyses of home range and movement data}

We used SYSTAT version 13 (Systat Software, San Jose, CA) to analyze home range and movement data. For comparison of mean annual home range and activity core sizes of males and non-gravid females we performed two-sample t-tests

We used analyses of variance with sex, season, and the interaction between sex and season as independent variables to compare the mean home range sizes (dependent variable) of male and non-gravid female snakes among seasons. We also compared the average distance moved between successive relocations (dependent variable) using ANOVA with sex, season, and the interaction between sex and season as independent variables.

We used Kolmogorov-Smirnov one-sample test with the Lilliefors option on residuals of each data set to test normality and Levene's test on absolute values of residuals of each data set to test homogeneous variance and to confirm assumptions of statistical analyses.

\section{Results}

\section{Annual home range}

We recorded a total of 383 observations for the ten snakes tracked from May 2016 to June 2017. We found that male snakes had a mean annual home range size of $26.02 \pm 11.53$ ha and a mean annual activity core size of $4.784 \pm 1.54$ ha (Table 2). We found that non-gravid female snakes had a mean annual home range size of $30.89 \pm 12.3$ ha and a mean annual activity core size of $6.90 \pm 3.71$ ha (Table 2).

Using two-sample t-tests, we found that there were no significant differences between mean annual home range sizes $\left(\mathrm{N}=9 ; \mathrm{t}_{8,0.025}=0.638, \mathrm{p}=0.541\right)($ Fig. 4$)$ nor activity core sizes $\left(\mathrm{t}_{8,0.025}=1.270 ; \mathrm{p}=0.240\right)$ (Fig. 5) of male and non-gravid female snakes. 


\section{Seasonal home range}

The mean home range and activity core sizes of male and non-gravid female snakes were smallest in the winter (December-February) and increased in size as the year progressed, with largest home range and activity core sizes occurring in the fall (September-November) (Table 3)(Fig. 6).

Using ANOVA of the mean home range sizes of males and non-gravid females among seasons, we found there were significant differences for the main effects of $\operatorname{sex}\left(\mathrm{N}=9 ; \mathrm{F}_{1,29,0.05}=8.978, \mathrm{p}=0.006\right)$ and season $\left(\mathrm{F}_{3,29,0.05}=28.739, \mathrm{p}=0.001\right)$, but no significant difference for the interaction between sex and season $\left(\mathrm{F}_{3,29,0.05}=2.532, \mathrm{p}=0.077\right)$. According to a posteriori Bonferroni pairwise comparison of the effect of season on mean home range size of both sexes of snakes in this population, the mean fall home range size was significantly larger than all other seasons $(\mathrm{p}=0.001)$ (Table 4$)$. Using pairwise comparison of the effect of season and sex on mean home range sizes we found that male snakes had significantly larger home ranges in fall compared to all other seasons. We also found that female snakes had larger home range sizes in fall compared to winter and spring (Table 5, Fig. 6).

We found that mean seasonal home range sizes of males and non-gravid females were statistically equal and followed a similar pattern of steady increase from winter to summer, but the home range size of male snakes increased more sharply than that of female snakes from summer to fall (Fig. 6). We also concluded that the mean fall home range size of male snakes $(25.30 \pm 6.08 \mathrm{ha})$ was larger than the mean home range size of female snakes $(14.74 \pm 2.48 \mathrm{ha})$, but they did not statistically differ $(\mathrm{p}=0.249)$ (Table 5$)$.

\section{Movement}

We found that, annually, non-gravid females traveled an average of $54.36 \pm 34.06 \mathrm{~m}$ between successive relocations, and males traveled an average of $62.73 \pm 48.43 \mathrm{~m}$ (Table 6). Using an ANOVA comparing the effects of sex, season, and the interaction of the effects of sex and season on the average distances moved between successive relocations indicated a significant difference for only the effect of season $(\mathrm{N}=9$; Sex: $\mathrm{F}_{1,79,0.05}=1.447, \mathrm{p}=0.233$; season: $\mathrm{F}_{3,79,0.05}=17.397, \mathrm{p}<0.001$; interaction: $\left.\mathrm{F}_{3,79,0.05}=0.516, \mathrm{p}=0.672\right)$. We concluded that snakes in this population moved significantly longer distances in summer and fall than winter and spring (Table 7, Fig. 7) using the a posterioriBonferroni pairwise comparison of the effect of season on average distance moved between successive relocations.

We also found that male and female snakes did not statistically differ in their average distances moved during any season (Table 8). Both male and female snakes shared the same annual trend, increasing distance moved between successive relocations from winter to fall (Fig. 8).

\section{Discussion}

The spatial ecology of the Timber Rattlesnake has been well studied in the northeastern and central parts of its distribution, but little is known of southern populations. Because temperature, habitat type, and prey composition and abundance dictate many aspects of reptile behavior, populations of conspecific species may exhibit behavioral differences across latitudinal and elevational gradients. Waldron et al. (2006a) indicated that Timber Rattlesnakes within a population in South Carolina had smaller mean annual home range sizes than conspecific populations in Virginia and New Jersey, with the New Jersey population having the largest home range. Furthermore, Mohr (2012) found Timber Rattlesnakes within a population in northeastern South Carolina moved shorter distances throughout the active season than populations previously studied at higher latitudes. Our study shows the same pattern of decreasing home range size from north to south.

Our analyses found that the annual home range sizes and average distances moved between successive relocations of males in the current study were statistically equal to those of non-gravid females (Figs. 6 and 7). Mohr (2012) also found that the average distances moved between relocations did not differ among sex within a population in the South Carolina mountains, but most other studies found male Timber Rattlesnakes had larger home range sizes and moved further distances than gravid and non-gravid female snakes (Reinert and Rupert 1999, Reinert and Zappalorti 1988, Rudolph and Burgdorf 1997, Sealy 2002, Waldron et al. 2006a, Waldron et al, 2006b). It is not clear why home range sizes of snakes in our study's population are 
so small, but prey density, habitat quality, climatic factors, body size, and reproductive female density have all been shown to affect home range sizes (Bjorneraas et al. 2011, Carrasco-Harris et al. 2020, Harestad and Bunnel 1979, Lendrum et al. 2014).

Because sit-and-wait predators, like Timber Rattlesnakes, will remain concealed in a location until a prey item comes within a close enough proximity to capture it, or until the probability of obtaining a prey item decreases enough to warrant moving to a new location, they may rely on high quality foraging habitats to gain energy (Schoener 1971). Both prey density and suitable microhabitat availability may affect an area's foraging quality (Beaupre 2008, Clark 2004a, Clark 2004b, Reinert et al. 2011). Many populations of Timber Rattlesnakes travel long distances to get from their winter den to summer foraging grounds. The transient habitat in between the den and foraging grounds may be suitable for thermoregulation, but not foraging (Brown 1992). Temperate rattlesnakes, like many other ectotherms, must obtain enough energy from food intake to satisfy energy requirements before temperatures become too low for activity. An increase in the amount of time a snake spends traveling between foraging sites may result in a net decrease in energy at the end of the active season. If energy requirements are not met, the snake may not be able to maintain its current lifestyle (Schoener 1971). During this study, there was an absence of long movements away from hibernacula in the spring. In fact, snakes were observed foraging within $2 \mathrm{~m}$ of known hibernacula. This likely indicates that prey availability and foraging habitat quality are high enough that snakes in this population have no need to travel long distances to foraging sites. Individuals may only have to travel far enough that competition between conspecifics is low. This could also play a role in the small home range sizes of snakes in this population.

The study area is mostly a contiguously forested landscape, but there are two major highways that run through it, bordering most of the study sites (Fig. 3). There are also small patches of commercial and residential development within the area. Roads may act as physical barriers that prevent snakes from crossing them (Andrews and Gibbons 2005) and as genetic barriers that prevent neighboring populations from exchanging genetic material (Clark et al. 2010). Species hesitant to cross open spaces, such as large, heavy-bodied snakes, like the Timber Rattlesnake, are especially susceptible to road barriers (Andrews and Gibbons 2005).

Every home range within this study was bordered by a paved or gravel road. Five of the snakes within this study crossed small gravel roads, but none crossed paved roads throughout the entire study. This could indicate either, the paved roads were acting as impervious barriers, or the snakes did not travel across these roads because the habitat, prey density, or some other variable across the road is of lower quality. Site B, Site F, and the road adjacent to these sites are located on a narrow natural levee formed by an abandoned distributary of the Mississippi River, providing a small area of slightly higher elevation than the surrounding areas. The land directly across the road is forested, but abruptly turns to marsh and open water. The habitat across the road adjacent to Site $\mathrm{M}$ has been clear cut or developed, and site $\mathrm{H}$ is bordered by water and commercial development on all sides. These habitats may not be suitable for Timber Rattlesnakes, so an attempt to cross the road may not be profitable for snakes in this population.

In our study, we found that seasonal home ranges and movements of male and female snakes were not statistically different from each other, but males did have larger average home range sizes and movements than females in September-November (Fall) (Fig. 6 and 8). These increases in home range size and movement seemed to coincide with the breeding season, which took place from early July until the end of November. An increase in home range size and movements is common for male snakes searching for receptive females in other populations of the Timber Rattlesnake. Even though there was an increase in home range size for males during the breeding season in southeastern Louisiana, it was not as drastic as found in other populations (Anderson 2015, Lind and Beaupre 2015, Reinert and Zappalorti 1988, Waldron et al. 2006b). Longer term studies with larger sample sizes are needed to retest these results.

Currently, there are many gaps in information regarding geographical differences in behaviors and life history traits of Timber Rattlesnake populations. Understanding the causes and effects of these differences at a local level may help mitigate some of the fallacies of conservation efforts that exist from extrapolating information from studies of populations that are spatially distant. This baseline study of the spatial ecology of 
a population of Timber Rattlesnakes in southeastern Louisiana is another step towards a better understanding of this species.

\section{Acknowledgements}

Much gratitude should be given to Dr. Brian Crother, Dr. Jeremiah Doody, and Dr. Clifford Fontenot for all the guidance given during this project. Also, thank you to the U.S. Department of Wildlife and Fisheries in Lacombe, La, for all of their help. This study was partially funded through the Edward. G. Schlieder Foundation.

\section{Disclosure Statement}

The authors of this manuscript have no conflicts of interest.

\section{Data Accessibility}

If editors decide that manuscript will be published, data will be uploaded to one of the approved databases before publication.

\section{Protection of Human and Animal Subjects in Research}

All activities performed for this study were done so under IACUC protocol \#0035 approved by the Southeastern Louisiana University IACUC on $3 / 21 / 2016$.

\section{Literature Cited}

Aldridge, R., and D. Duvall. 2002. Evolution of the mating season in the pitvipers of North America. Herpetological Monographs 16:1-25.

Anderson, C. 2015. Variation in male movement paths during the mating season exhibited by the Timber Rattlesnake (Crotalus horridus) in St. Louis County, Missouri. Herpetology Notes 8:267-274.

Andrews, K., and J. Gibbons. 2008. Roads as catalysts of urbanization: Snakes on roads face differential impacts due to inter-and intraspecific ecological attributes. Pp. 145-153, In J.C. Mitchell, R.E. Jung Brown, B. Bartholomew (Eds.) Urban herpetology. Society for the Study of Amphibians and Reptiles, US. 586 pp.

Andrews, K., and J. Gibbons. 2005. How do highways influence snake movement? Behavioral responses to roads and vehicles. Copeia 2005:772-782.

Bauder, J.M., D.R. Breininger, M.R. Bolt, M.L. Legare, C.L. Jenkins, B.B. Rothermel, and K. McGarigal. 2016. The influence of sex and season on conspecific spatial overlap in a large, actively-foraging colubrid snake. PLoS ONE 11(8): e0160033. Available online at https://doi.org/10.1371/journal.pone.0160033. Accessed 11 November 2018.

Beaupre, S. 2008. Annual variation in time-energy allocation by Timber Rattlesnakes (Crotalus horridus ) in relation to food acquisition. Pp. 111-121. In W.K. Hayes, S.P. Bush, D. Caldwell, and K. Beaman (Eds.) Biology of Rattlesnakes. Loma Linda Press, US. 606 pp.

Beaupre, S.J., and L.E. Douglas. 2009. Snakes as indicators and monitors of ecosystem properties. Pp. 244261, In S. Mullin and R.A. Siegel (Eds.) Snakes: Ecology and Conservation. Cornell University Press, US. $384 \mathrm{pp}$.

Bjørneraas, K., I. Herfindal, E. Solberg, B. Sæther, B. Van Moorter, and C. Rolandsen. 2012. Habitat quality influences population distribution, individual space use and functional responses in habitat selection by a large herbivore. Oecologia 168:231-243.

Bonnet, X., and G. Naulleau. 1996. Catchability in snakes: consequences for estimates of breeding frequency. Canadian Journal of Zoology 74:233-239. 
Brown, W.S., D.W. Pyle, K.R. Greene, and J.B. Friedlaender. 1982. Movements and temperature relationships of Timber Rattlesnakes (Crotalus horridus ) in northeastern New York. Journal of Herpetology $16: 151-161$.

Brown, W.S. 1992. Emergence, ingress, and seasonal captures at dens of northern timber Rattlesnakes, Crotalus horridus . Pp. 251-258, In J.A. Campbell and E.D. Brodie (Eds.) Biology of the Pitvipers. Selva Publishing, US. 467 pp.

Burger, J., R. Zappalorti, M. Gochfeld, E. DeVito, D. Schneider, M. McCort, and C. Jeitner. 2012. Long-term use of hibernacula by Northern Pinesnakes (Pituophis melanoleucus ). Journal of Herpetology 46:596-601.

Carrasco-Harris, M.F., J.A. Cole, and S. Reichling. 2021. Cozy in the City: The Morphology and Spatial Ecology of Copperheads in an Urban Forest. Urban Naturalist 35:1-19.

Carfagno, G. L., and P. J. Weatherhead. 2008. Energetics and space use: intraspecific and interspecific comparisons of movements and home ranges of two Colubrid snakes. Journal of Animal Ecology 77:416-424.

Clark, R.W. 2004a. Feeding experience modifies the assessment of ambush sites by the Timber Rattlesnake, a sit-and-wait predator. Ethology 110:471-483.

Clark, R.W. 2004b. Timber Rattlesnakes (Crotalus horridus) use chemical cues to select ambush sites. Journal of Chemical Ecology 30:607-617.

Clark, R.W., W. Brown, R. Stechert, and K. Zamudio. 2010. Roads, interrupted dispersal, and genetic diversity in Timber Rattlesnakes. Conservation Biology 24:1059-1069.

Dundee, H.A., and D.A. Rossman. 1989. The Amphibians and Reptiles of Louisiana. Louisiana State University Press, US. 300 pp.

Ernst, C.H., and E.M. Ernst. 2011. Venomous Reptiles of the United States, Canada, and Northern Mexico. Vol. 2. John Hopkins University Press, Baltimore, Maryland. 424 pp.

ESRI, 2011. ArcGIS Desktop: Release 10. Redlands, California: Environmental Systems Research Institute.

Gomez, L., K.W. Larsen, and P.T. Gregor. 2015. Contrasting patterns of migration and habitat use in neighboring rattlesnake populations. Journal of Herpetology 49:371-376.

Greene, H., and J. Campbell. 1992. The future of pitvipers. Pp. 421-427In J.A. Campbell and E.D. Brodie (Eds.) Biology of the Pitvipers. Selva Publishing, US. 467 pp.

Harestad, A., and F. Bunnel. 1979. Home range and body weight- A reevaluation. Ecology 60:389-402.

Hoss, S.K., G.W. Schuett, RL. Earley, and L.L. Smith. 2011. Reproduction in male Crotalus adamanteus Beauvois (Eastern Diamond-Backed Rattlesnake): Relationship of plasma testosterone to testis and kidney dimensions and the mating season. Southeastern Naturalist 10:95-108.

Howard, J. J. 2012. Hurricane Katrina impact on a leveed bottomland hardwood forest in Louisiana. The American Midland Naturalist 168:56-69.

Klug, P. E., and S.M. Wisely. 2011. Population genetic structure and landscape connectivity of the Eastern Yellowbelly Racer (Coluber constrictor flaviventris ) in the contiguous tallgrass prairie of northeastern Kansas, USA. Landscape ecology 26:281-294.

Lendrum, P.E., L.M. Elbroch, H. Quigley, D. Craighead, M. Jimenez, and D. Craighead. Home range characteristics of a subordinate predator: Selection for refugia or hunt opportunity?. Journal of Zoology 294:58-66.

Lind, C. M., and S.J. Beaupre. 2015. Male snakes allocate time and energy according to individual energetic status: Body condition, steroid hormones, and reproductive behavior in Timber Rattlesnakes, Crotalus horridus . Physiological and Biochemical Zoology 88:624-633. 
Martin, W. H. 1992. The Timber Rattlesnake: Its distribution and natural History. (Pp. 13-21). In T.F. Tyning (Ed.). Conservation of the Timber Rattlesnake in the Northeast. Massachusetts Audubon Society, US. 40 pp.

Mohr, J.R. 2012. Movements of the Timber Rattlesnake (Crotalus horridus ) in the South Carolina Mountains. Bulletin of the Florida Museum of Natural History 51:269.

Naulleau, G., and X. Bonnet. 1996. Body condition threshold for breeding in a viviparous snake. Oecologia 107:301-306.

Powell, R., R. Conant, and J.T. Collins. 2016. A Field Guide to Reptiles and Amphibians. Eastern and Central North America. 4th edition. Houghton Mifflin Company, US. 494 pp.

Reed, R., and M. Douglas. 2002. Ecology of the Grand Canyon Rattlesnake (Crotalus viridis abyssus ) in the Little Colorado River Canyon, Arizona. The Southwestern Naturalist 47:30-39.

Reinert, H.K., and D. Cundall. 1982. An improved surgical implantation method for radio-tracking snakes. Copeia 1982:702-705.

Reinert, H.K., G. MacGregor, M. Esch., L. Bushar, and R. Zappalorti. 2011. Foraging ecology of Timber Rattlesnakes, Crotalus horridus . Copeia, 2011:430-442.

Reinert, H.K., and R. Rupert. 1999. Impacts of translocation on behavior and survival of Timber Rattlesnakes, Crotalus horridus . Journal of Herpetology 33:45-61.

Reinert, H.K., and R. Zappalorti. 1988. Timber Rattlesnakes (Crotalus horridus) of the pine barrens: Their movement patterns and habitat preference. Copeia 1988:964-978.

Rodgers, A.R., J.G. Kie, D. Wright, H.L. Beyer, and A.P. Carr. 2015. HRT: Home range tools for ArcGIS. Version 2.0. Ontario Ministry of Natural Resources and Forestry, Centre for Northern Forest Ecosystem Research, Thunderbay, Ontario.

Rodríguez-Robles, J.A. 2003. Home ranges of Gopher Snakes (Pituophis catenifer, Colubridae) in central California. Copeia 2003:391-396.

Rudolph, D.C., and S.J. Burgdorf. 1997. Timber Rattlesnakes and Louisiana Pine Snakes of the west Gulf Coastal Plain: Hypotheses of Decline. The Texas Journal of Science 49:111-122.

Schoener, T. 1971. Theory of feeding strategies. Annual Review of Ecology and Systematics 2:369-404.

Sealy, J.B. 2002. Ecology and behavior of the Timber Rattlesnake (Crotalus horridus) in the upper Piedmont of North Carolina: Identified threats and conservation recommendations. Pp. 561-578,In G.W. Schuett, M. Hoggren, M.E. Douglas, and H.W. Greene (Eds.) Biology of the Vipers. Eagle Mountain Publishing, U.S. $580 \mathrm{pp}$.

Schuett, G.W., R.A. Repp, and S.K. Hoss. 2011. Frequency of reproduction in female Western Diamondbacked Rattlesnakes from the Sonoran Desert of Arizona is variable in individuals: Potential role of rainfall and prey densities. Journal of Zoology 284:105-113.

Újvári, B., and Z. Korsós. 2000. Use of radiotelemetry on snakes: A review. Acta Zoologica Academiae Scientiarum Hungaricae 46:115-146.

Waldron, J.L., S.H. Bennet, S.M. Welch, M.E. Dorcas, J.D. Lanham, and W. Kalinowski. 2006a. Habitat specificity and home-range size as attributes of species vulnerability to extinction: A case study using sympatric rattlesnakes. Animal Conservation 9:414-420.

Waldron, J. L., J.D. Lanham, and S.H. Bennett. 2006b. Using behaviorally-based seasons to investigate Canebrake Rattlesnake (Crotalus horridus ) movement patterns and habitat selection. Herpetologica 62:389398. 
Wall, D. P., and S.P. Darwin. 1999. Vegetation and elevational gradients within a bottomland hardwood forest of southeastern Louisiana. The American Midland Naturalist 142:17-30.

Worton, B. J. 1989. Kernel methods for estimating the utilization distribution in home-range studies. Ecology 70:164-168.

Table 1. Individual study snake information.

\begin{tabular}{llllllll}
\hline Snake ID & Sex & $\begin{array}{l}\text { Capture } \\
\text { date }\end{array}$ & Study Site & $\begin{array}{l}\text { Days } \\
\text { tracked }\end{array}$ & SVL $(\mathrm{cm})$ & $\begin{array}{l}\text { Total length } \\
(\mathrm{cm})\end{array}$ & Weight $(\mathrm{kg})$ \\
$350-1$ & $\mathrm{M}$ & $4 / 2 / 2016$ & Site B & 342 & 118 & 137 & 1.369 \\
$350-2$ & $\mathrm{~F}$ & $4 / 2 / 16$ & Site B & 342 & 126 & 135 & 2.323 \\
$350-3$ & $\mathrm{M}$ & $4 / 2 / 16$ & Site B & 349 & 168 & 182 & 3.410 \\
$350-4$ & $\mathrm{M}$ & $4 / 10 / 16$ & Site F & 348 & 132 & 144 & 1.708 \\
$350-5$ & $\mathrm{M}$ & $4 / 10 / 16$ & Site F & 242 & 114 & 124 & 1.205 \\
$350-7$ & $\mathrm{M}$ & $4 / 5 / 16$ & Site F & 351 & 138 & 149 & 1.498 \\
$530-2$ & $\mathrm{~F}$ & $4 / 8 / 16$ & Site H & 366 & 134 & 142 & 1.558 \\
$530-3$ & $\mathrm{~F}$ & $4 / 10 / 16$ & Site H & 58 & 120 & 128 & 0.944 \\
$250-1$ & $\mathrm{~F}$ & $5 / 22 / 16$ & Site M & 352 & 125 & 134 & 2.160 \\
$250-2$ & $\mathrm{M}$ & $6 / 15 / 16$ & Site M & 355 & 141 & 150 & 2.205 \\
$350-8$ & $\mathrm{M}$ & $5 / 20 / 16$ & Site B & 363 & 138 & 150 & 2.334 \\
\hline
\end{tabular}

Table 2. Average home range and activity core sizes of a population of Timber rattlesnakes in southeastern Louisiana

\begin{tabular}{llll}
\hline Home range (ha) 90\% Isopleth & Activity core (ha) 50\% Isopleth & Home range (ha) 90\% Isopleth & Activity core (ha) $50 \%$ \\
\hline Males & Males & Non-gravid females & Non-gravid females \\
$26.0 \pm 11.5$ & $4.8 \pm 1.5$ & $30.9 \pm 12.3$ & $6.9 \pm 3.7$ \\
\hline
\end{tabular}

Table 3. Seasonal home range and activity center sizes of Crotalus horridus in southeastern Louisiana.

\begin{tabular}{|c|c|c|c|c|}
\hline Season & $\begin{array}{l}\text { Mean home range } \\
\text { size of males (ha) } \\
\text { (Minimum) } \\
\text { \{Maximum\} 90\% } \\
\text { Isopleth }\end{array}$ & $\begin{array}{l}\text { Mean home range } \\
\text { size of females (ha) } \\
\text { (Minimum) } \\
\text { Maximum } 90 \% \\
\text { Isopleth }\end{array}$ & $\begin{array}{l}\text { Mean activity } \\
\text { center size of males } \\
\text { (ha) (Minimum) } \\
\text { \{Maximum } 50 \% \\
\text { Isopleth }\end{array}$ & $\begin{array}{l}\text { Mean activity } \\
\text { center size of } \\
\text { females (ha) } \\
\text { (Minimum) } \\
\text { \{aximum } 50 \% \\
\text { Isopleth }\end{array}$ \\
\hline December- February & $\begin{array}{l}0.74 \pm 1.08 \\
(0.03)\{2.33\}\end{array}$ & $\begin{array}{l}1.40 \pm 1.52 \\
(0.32)\{2.47\}\end{array}$ & $\begin{array}{l}0.16 \pm 0.22 \\
(0.01)\{0.45\}\end{array}$ & $\begin{array}{l}0.45 \pm 0.34 \\
(0.21)\{0.70\}\end{array}$ \\
\hline March- May & $\begin{array}{l}8.70 \pm 3.50 \\
(3.40)\{12.81\}\end{array}$ & $\begin{array}{l}4.70 \pm 2.89 \\
(0.48)\{7.41\}\end{array}$ & $\begin{array}{l}2.03 \pm 1.22 \\
(0.60)\{3.27\}\end{array}$ & $\begin{array}{l}1.20 \pm 0.60 \\
(0.46)\{1.68\}\end{array}$ \\
\hline June- August & $\begin{array}{l}11.76 \pm 4.41 \\
(7.01)\{19.55\}\end{array}$ & $\begin{array}{l}9.07 \pm 5.19 \\
(4.87)\{17.22\}\end{array}$ & $\begin{array}{l}3.01 \pm 1.14 \\
(1.34)\{4.91\}\end{array}$ & $\begin{array}{l}2.25 \pm 0.94 \\
(1.35)\{3.22\}\end{array}$ \\
\hline $\begin{array}{l}\text { September- } \\
\text { November }\end{array}$ & $\begin{array}{l}25.30 \pm 6.08 \\
(21.83)\{34.36\}\end{array}$ & $\begin{array}{l}14.74 \pm 2.48 \\
(12.84)\{18.05\}\end{array}$ & $\begin{array}{l}6.45 \pm 1.50 \\
(4.93)\{8.52\}\end{array}$ & $\begin{array}{l}5.75 \pm 3.11 \\
(3.21)\{10.25\}\end{array}$ \\
\hline
\end{tabular}

Table 4: Results of Bonferroni pairwise comparison of the effect of season on average home range size of male and non-gravid female Crotalus horridus . 


\begin{tabular}{llll}
\hline & Dec-Feb & Mar-May & Jun-Aug \\
\hline Dec-Feb & $\mathrm{X}$ & $\mathrm{X}$ & $\mathrm{X}$ \\
Mar-May & 0.031 & $\mathrm{X}$ & $\mathrm{X}$ \\
Jun-Aug & $<0.001$ & $* 0.108$ & $\mathrm{X}$ \\
Sept-Nov & $<0.001$ & $<0.001$ & $<0.001$ \\
\hline
\end{tabular}

${ }^{1}$ Numbers in columns represent p-values of Bonferroni test

$2 *=$ non-significant result

Table 5: Results of Bonferroni pairwise comparison of seasonal home range sizes of male and non-gravid female Crotalus horridus in southeastern Louisiana.

\begin{tabular}{|c|c|c|c|c|c|c|c|}
\hline & Dec-Feb (F) & $\begin{array}{l}\text { Dec-Feb } \\
(\mathrm{M})\end{array}$ & $\begin{array}{l}\text { Mar-May } \\
\text { (F) }\end{array}$ & $\begin{array}{l}\text { Mar-May } \\
\text { (M) }\end{array}$ & $\begin{array}{l}\text { Jun- Aug } \\
\text { (F) }\end{array}$ & $\begin{array}{l}\text { Jun- Aug } \\
\text { (M) }\end{array}$ & $\begin{array}{l}\text { Sep- Nov } \\
\text { (F) }\end{array}$ \\
\hline Dec-Feb (F) & $\mathrm{X}$ & X & $\mathrm{X}$ & X & X & X & X \\
\hline $\begin{array}{l}\text { Dec-Feb } \\
\text { (M) }\end{array}$ & $* 0.664$ & $\mathrm{X}$ & $\mathrm{X}$ & $\mathrm{X}$ & $\mathrm{X}$ & $\mathrm{X}$ & $\mathrm{X}$ \\
\hline $\begin{array}{l}\text { Mar-May } \\
\text { (F) }\end{array}$ & $* 1.000$ & $* 1.000$ & $\mathrm{X}$ & $\mathrm{X}$ & $\mathrm{X}$ & $\mathrm{X}$ & $\mathrm{X}$ \\
\hline $\begin{array}{l}\text { Mar-May } \\
(\mathrm{M})\end{array}$ & $* 1.000$ & 0.042 & $* 1.000$ & $\mathrm{X}$ & $\mathrm{X}$ & $\mathrm{X}$ & $\mathrm{X}$ \\
\hline $\begin{array}{l}\text { Jun- Aug } \\
\text { (F) }\end{array}$ & *0.399 & 0.040 & $* 1.000$ & $* 1.000$ & $\mathrm{X}$ & $\mathrm{X}$ & $\mathrm{X}$ \\
\hline $\begin{array}{l}\text { Jun- Aug } \\
(\mathrm{M})\end{array}$ & 0.027 & 0.001 & $* 0.051$ & $* 1.000$ & $* 1.000$ & $\mathrm{X}$ & $\mathrm{X}$ \\
\hline $\begin{array}{l}\text { Sep- Nov } \\
\text { (F) }\end{array}$ & 0.004 & $<0.001$ & 0.006 & $* 0.352$ & $* 0.634$ & $* 1.000$ & $\mathrm{X}$ \\
\hline $\begin{array}{l}\text { Sep- Nov } \\
\text { (M) }\end{array}$ & $<0.001$ & $<0.001$ & $<0.001$ & $<0.001$ & $<0.001$ & 0.005 & $* 0.249$ \\
\hline
\end{tabular}

${ }^{1}$ Numbers in columns represent p-values of Bonferroni test

$2 *=$ non-significant result

Table 6: Seasonal average distance traveled between successive relocations by male and non-gravid female Crotalus horridus in southeastern Louisiana.

\begin{tabular}{lll}
\hline & Average distance traveled between relocation $(\mathrm{m})$ Males & Average distance traveled between relocation $(\mathrm{m}) \mathrm{F}$ \\
\hline Dec- Feb & $18.56 \pm 19.70$ & $25.92 \pm 27.72$ \\
Mar- May & $47.36 \pm 33.11$ & $30.43 \pm 15.63$ \\
Jun- Aug & $95.24 \pm 46.06$ & $70.91 \pm 44.25$ \\
Sept- Nov & $110.37 \pm 69.88$ & $100.87 \pm 19.03$ \\
\hline
\end{tabular}

Table 7: Results of Bonferroni pairwise comparison of the effect of season on average distance moved between successive relocations of Crotalus horridus in southeastern Louisiana.

\begin{tabular}{llll}
\hline & Dec- Feb & Mar- May & Jun- Aug \\
\hline Dec- Feb & $\mathrm{X}$ & $\mathrm{X}$ & $\mathrm{X}$
\end{tabular}




\begin{tabular}{llll}
\hline & Dec- Feb & Mar- May & Jun- Aug \\
\hline Mar- May & $* 1.000$ & $\mathrm{X}$ & $\mathrm{X}$ \\
Jun- Aug & $<0.001$ & 0.002 & $\mathrm{X}$ \\
Sept- Nov & $<0.001$ & $<0.001$ & ${ }^{*} 0.441$ \\
\hline
\end{tabular}

${ }^{1}$ Numbers in columns represent p-values of Bonferroni test

$2 *=$ non-significant result

Table 8: Results of Bonferroni pairwise comparison of the effect of season and sex on the average distances moved between successive relocations of Crotalus horridus in southeastern Louisiana.

\begin{tabular}{llllllll}
\hline & $\begin{array}{l}\text { Dec-Feb } \\
(\mathrm{F})\end{array}$ & $\begin{array}{l}\text { Dec-Feb } \\
(\mathrm{M})\end{array}$ & $\begin{array}{l}\text { Mar-May } \\
(\mathrm{F})\end{array}$ & $\begin{array}{l}\text { Mar-May } \\
(\mathrm{M})\end{array}$ & $\begin{array}{l}\text { Jun-Aug } \\
(\mathrm{F})\end{array}$ & $\begin{array}{l}\text { Jun- Aug } \\
(\mathrm{M})\end{array}$ & $\begin{array}{l}\text { Sep- Nov } \\
(\mathrm{F})\end{array}$ \\
\hline $\begin{array}{l}\text { Dec-Feb }(\mathrm{F}) \\
\text { Dec-Feb }\end{array}$ & $\mathrm{X}$ & $\mathrm{X}$ & $\mathrm{X}$ & $\mathrm{X}$ & $\mathrm{X}$ & $\mathrm{X}$ & $\mathrm{X}$ \\
$\begin{array}{l}\text { (M) } \\
\text { Mar-May }\end{array}$ & $* 1.000$ & $\mathrm{X}$ & $\mathrm{X}$ & $\mathrm{X}$ & $\mathrm{X}$ & $\mathrm{X}$ & $\mathrm{X}$ \\
$\begin{array}{l}\text { (F) } \\
\text { Mar-May } \\
(\mathrm{M})\end{array}$ & $* 1.000$ & $* 1.000$ & $\mathrm{X}$ & $\mathrm{X}$ & $\mathrm{X}$ & $\mathrm{X}$ & $\mathrm{X}$ \\
$\begin{array}{l}\text { Jun- Aug } \\
(\mathrm{F})\end{array}$ & $* 0.885$ & $* 1.000$ & $* 1.000$ & $\mathrm{X}$ & $\mathrm{X}$ & $\mathrm{X}$ & $\mathrm{X}$ \\
$\begin{array}{l}\text { Jun- Aug } \\
(\mathrm{M})\end{array}$ & 0.028 & $* 0.076$ & $* 0.697$ & $* 1.000$ & $\mathrm{X}$ & $\mathrm{X}$ & $\mathrm{X}$ \\
$\begin{array}{l}\text { Sep- Nov } \\
\text { (F) }\end{array}$ & 0.027 & 0.001 & 0.013 & $* 0.096$ & $* 1.000$ & $* 1.000$ & $\mathrm{X}$ \\
$\begin{array}{l}\text { Sep- Nov } \\
(\mathrm{M})\end{array}$ & 0.002 & $<0.001$ & $<0.001$ & 0.003 & $* 0.556$ & $* 1.000$ & $* 1.000$ \\
\hline
\end{tabular}

${ }^{1}$ Numbers in columns represent p-values of Bonferroni test

$2 *=$ non-significant result 


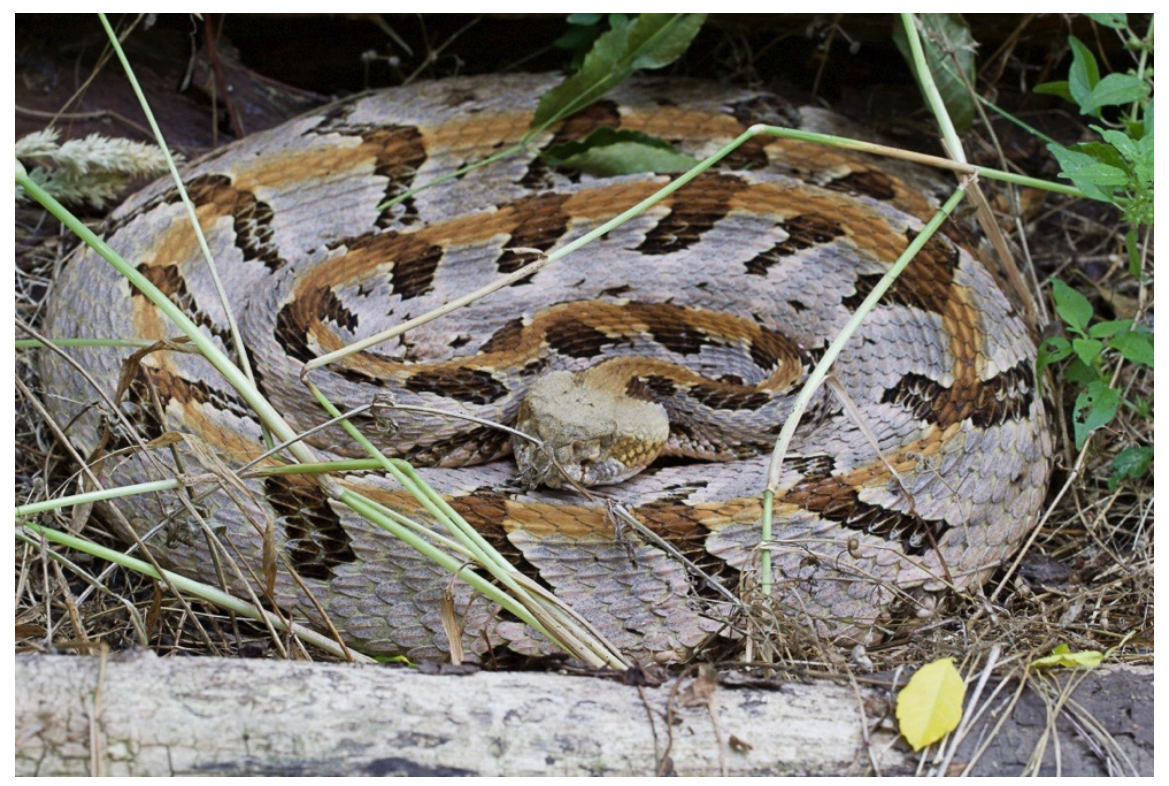

Figure 1: Crotalus horridus in foraging position. 


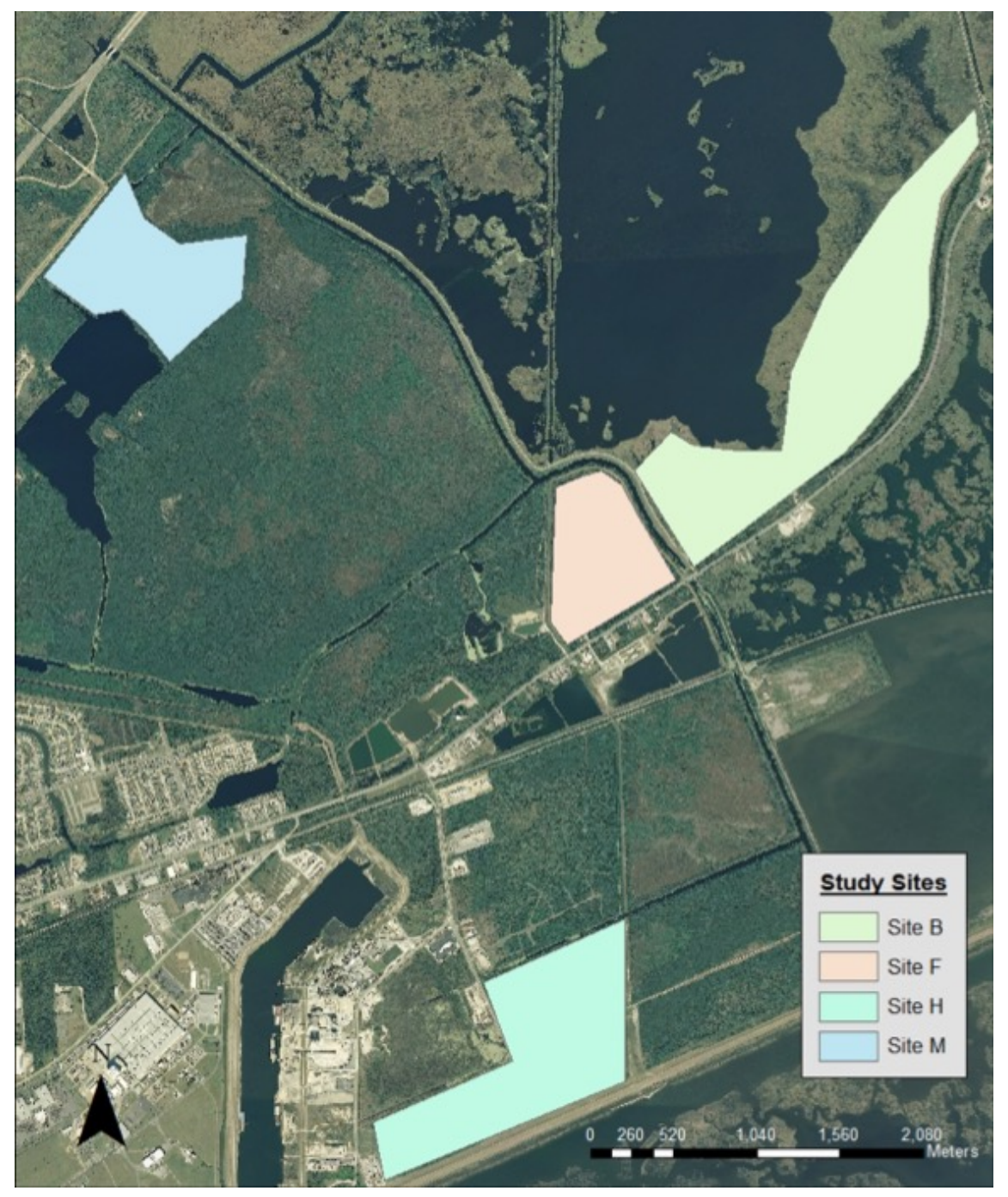

Figure 2: Map of southeastern Louisiana study sites. 


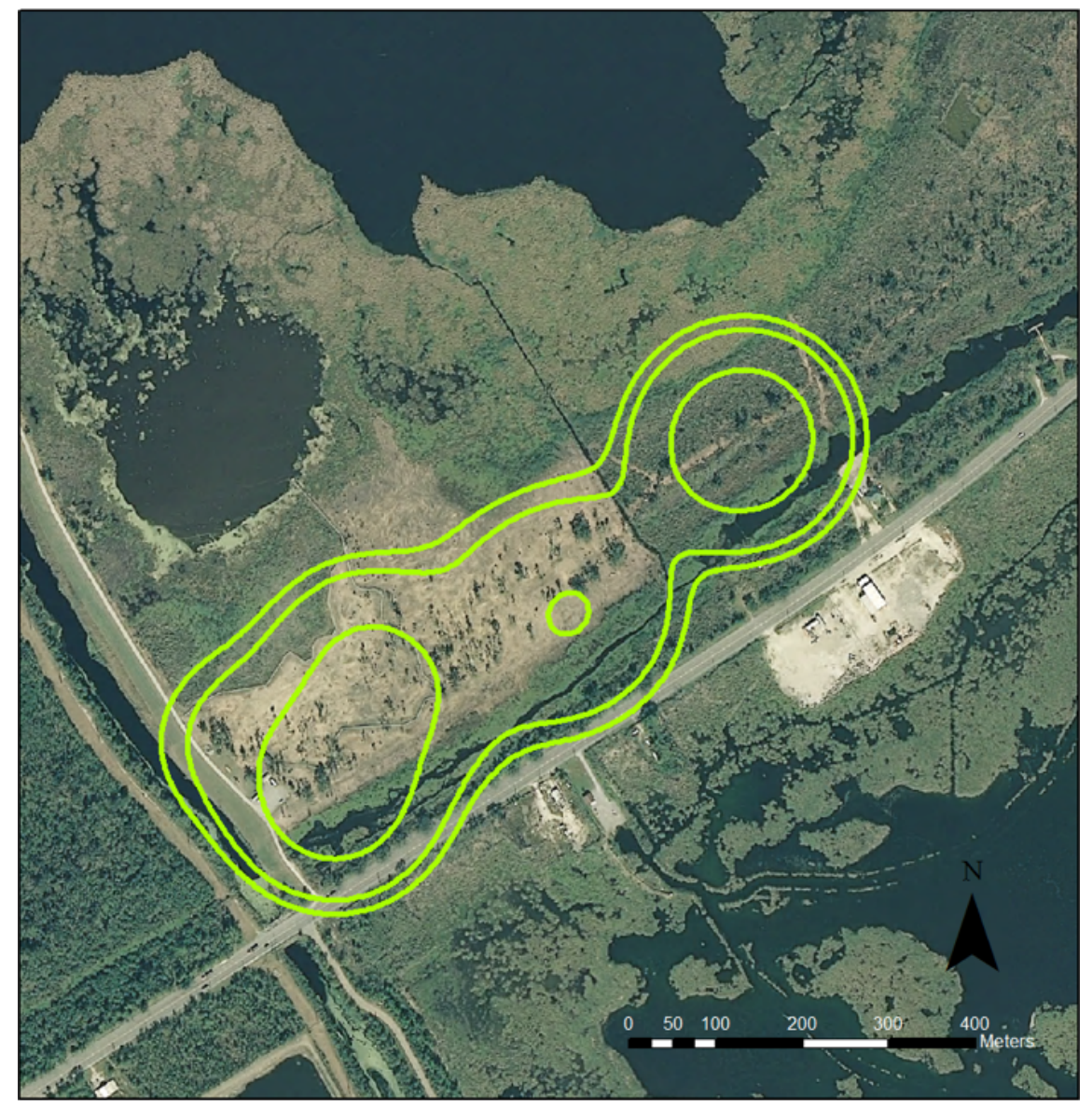

f

Figure 3: Polygon representing home range area (90\% isopleth) and activity core (50\% isopleth) of male Crotalus horridus, 350-3. 


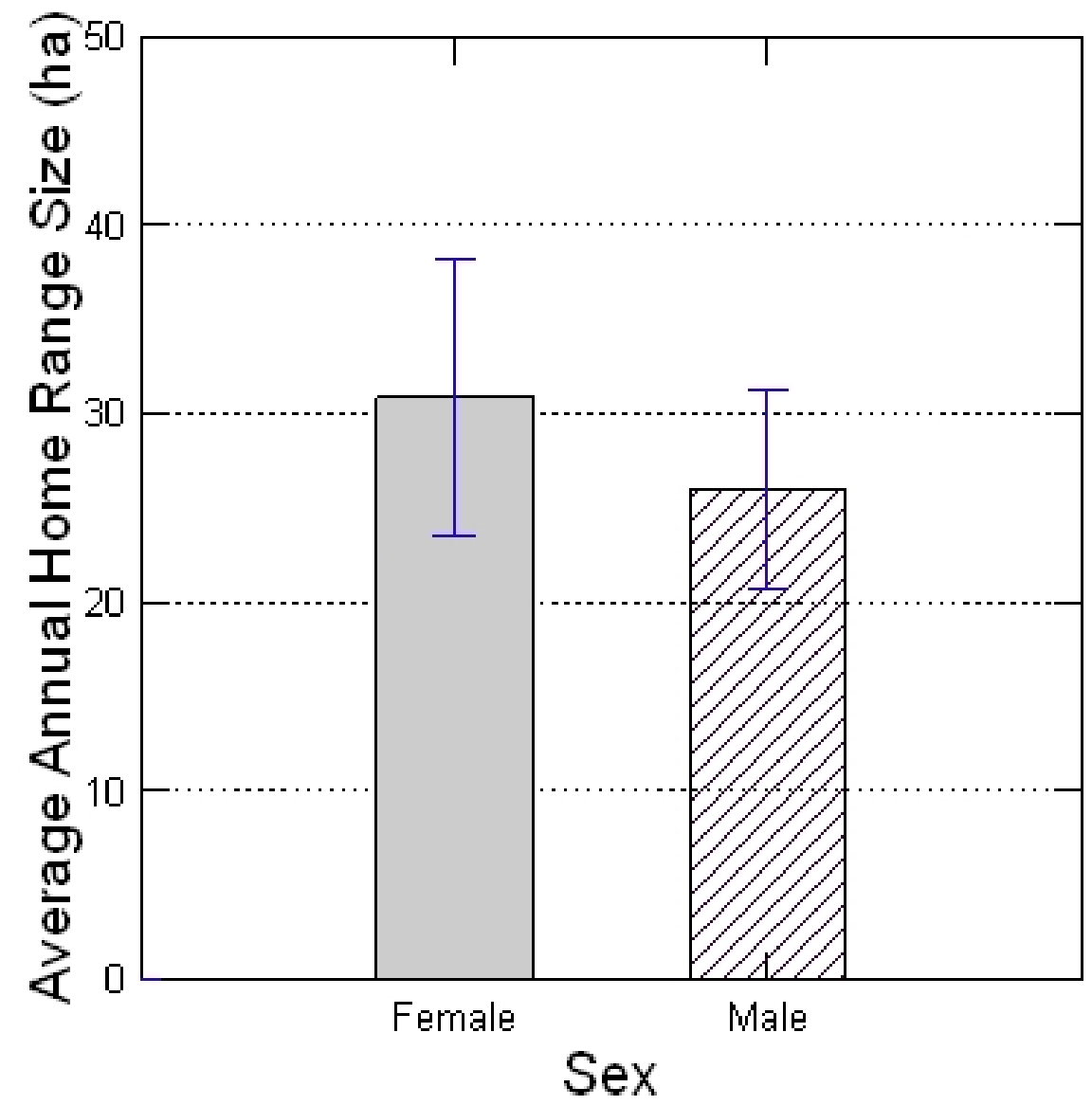

Figure 4: Average annual home range size (90\% Isopleth) of male and non-gravid female Crotalus horridus in southeastern Louisiana $(\mathrm{n}=9)$ 


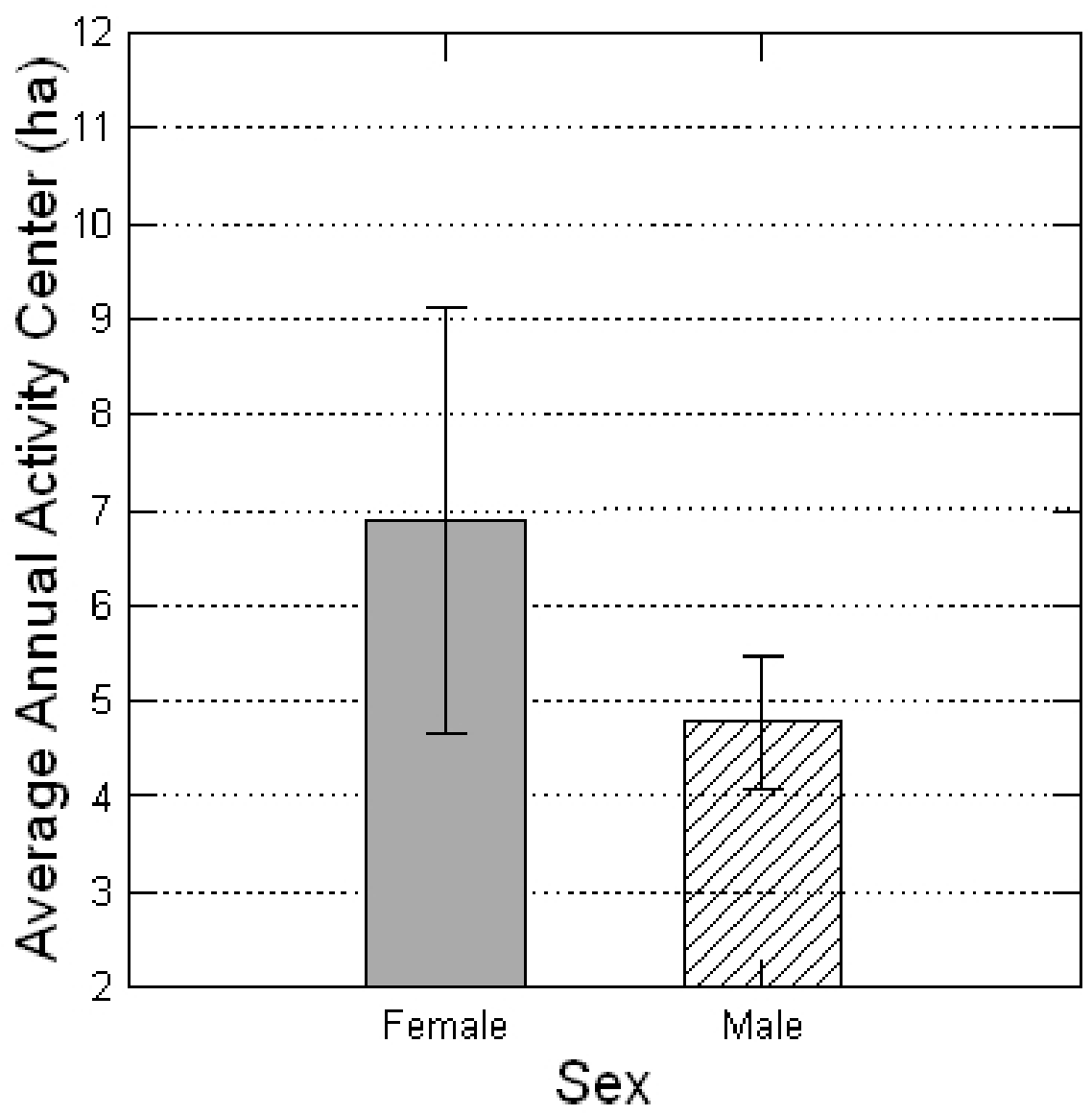

Figure 5 Figure 1: Map of southeastern Louisiana study sites.

: Average annual activity center size (50\% isopleth) of male and non-gravid females from a population of Crotalus horridus in southeastern Louisiana $(\mathrm{n}=9)$ 


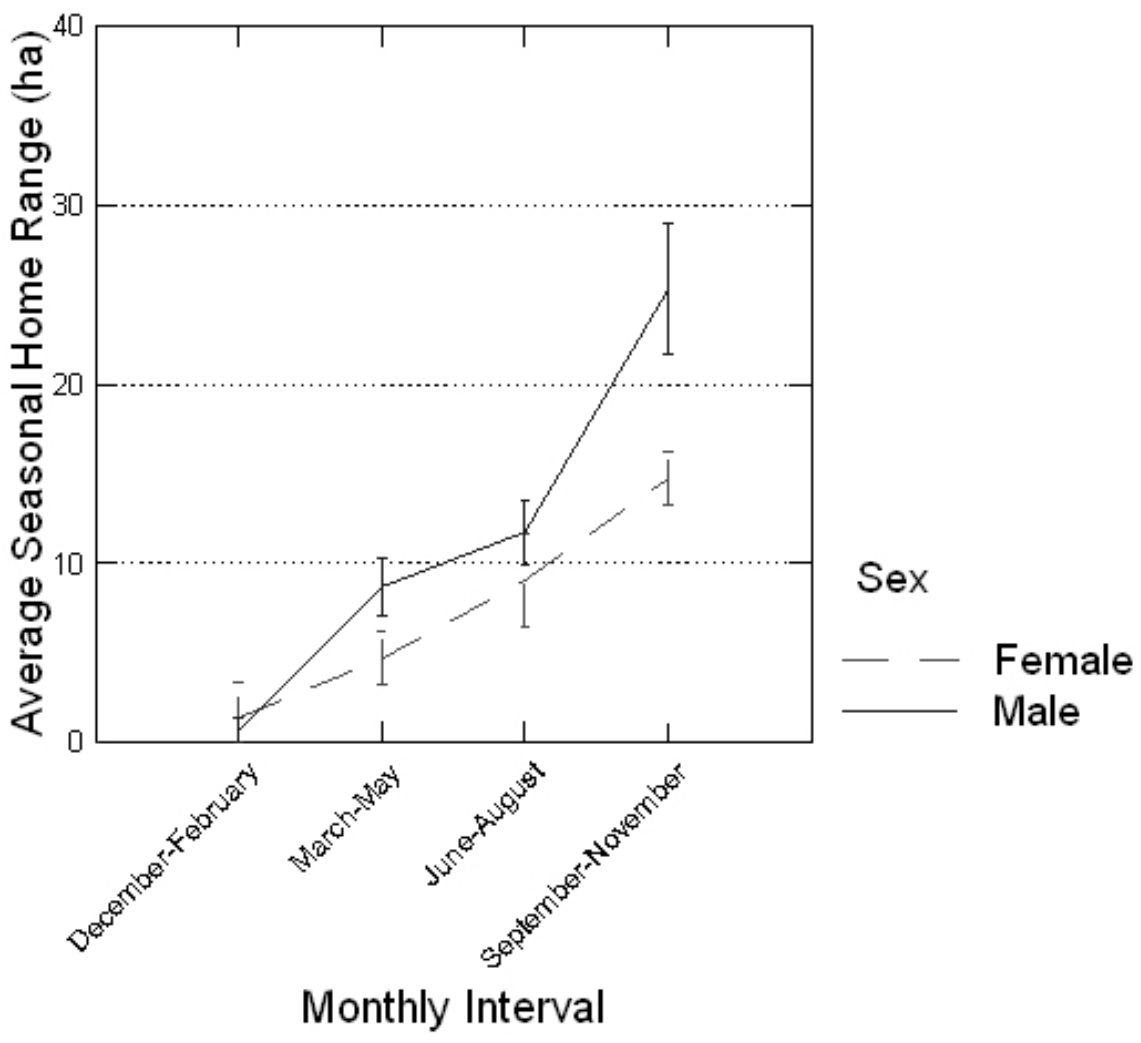

Figure 6: Average seasonal home range sizes of male and non-gravid female Crotalus horridus in southeastern Louisiana $(\mathrm{n}=9)$. 


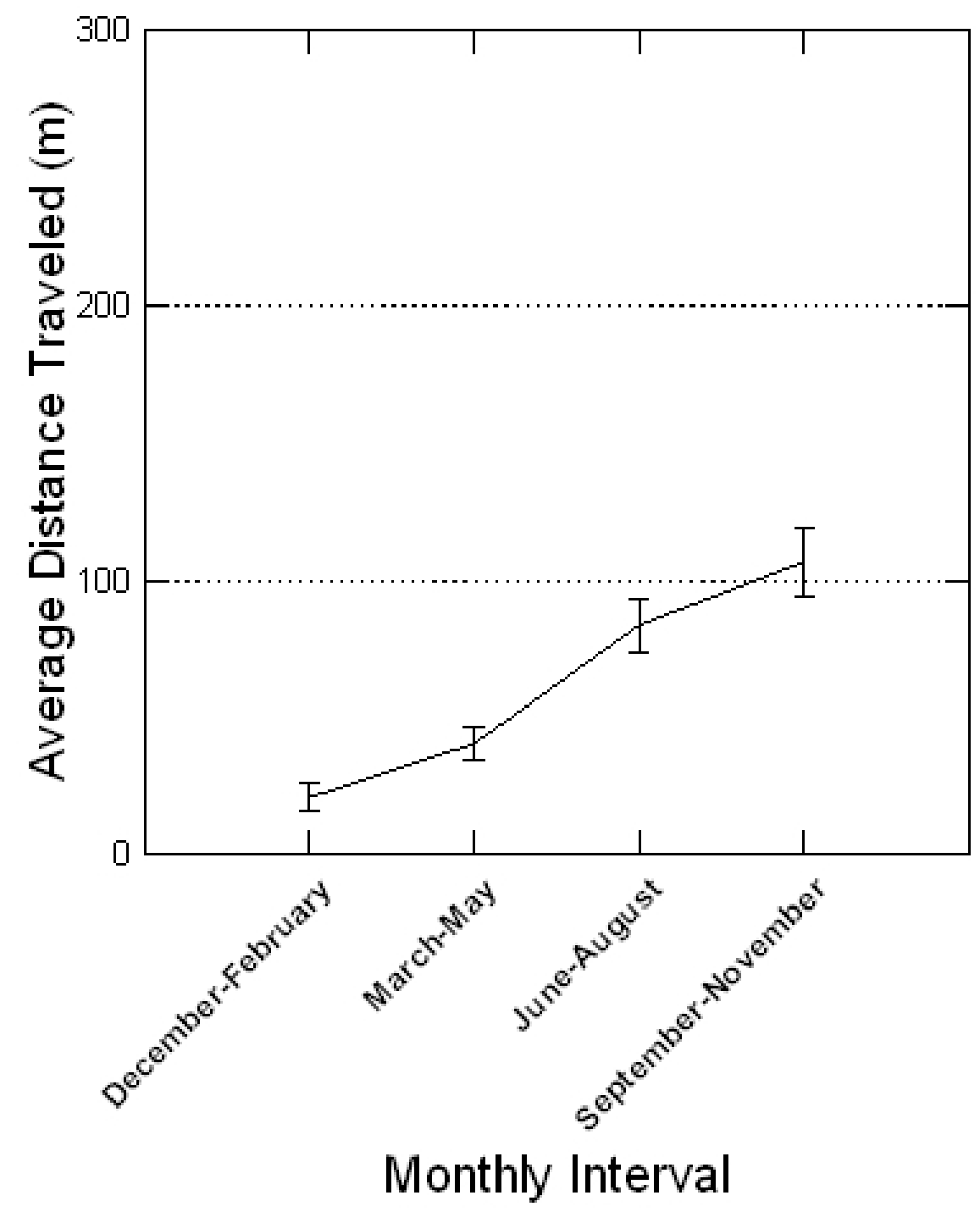

Figure 7: Seasonal average distance travelled between successive relocations by a population of Crotalus horridus in southeastern Louisiana $(\mathrm{n}=9)$. 


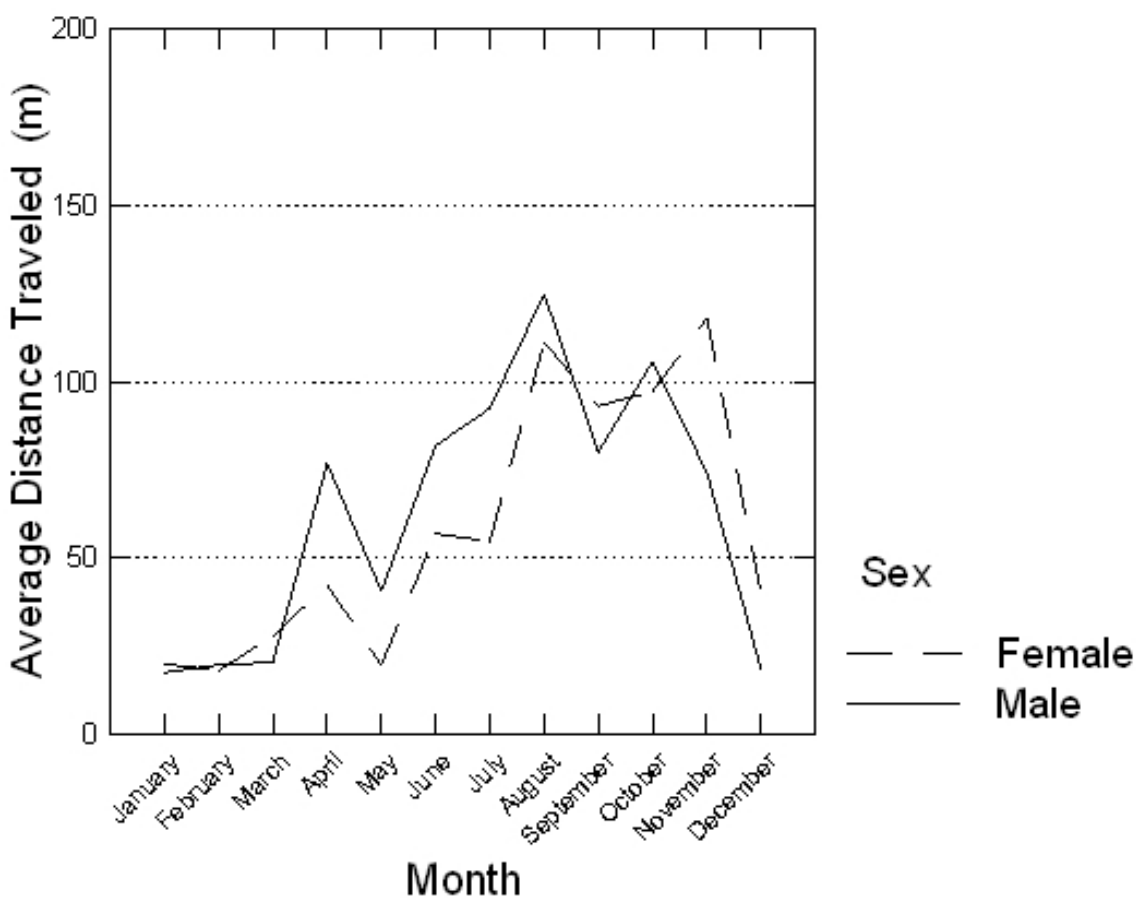

Figure 8: Monthly average distance travelled between successive relocations males and non-gravid females from a population of Crotalus horridus in southeastern Louisiana $(\mathrm{n}=9)$. 